\title{
Analisis Dampak Pandemi Corona Virus Terhadap Tingkat Kesadaran Masyarakat dalam Penerapan Protokol Kesehatan
}

Faura Dea Ayu Pinasti

Universitas Muhammadiyah Malang

Email: deaaaayu@gmail.com

\section{ARTICLE INFO}

Keyword:

Corona

Virus

Protocol

Health

Protokol

Kesehatan

\section{*) corresponding author}

Mahasiswa Jurusan Pendidikan Biologi Fakultas Keguruan dan Ilmu Pendidikan Universitas Muhammadiyah Malang

Jalan Raya Tlogomas, No. 246 Tlogomas, Babatan, Tegal Gondo, Kec. Lowok Waru, Kota Malang, Jawa Timur (65144)

\begin{abstract}
Corona virus is a new type of virus that is now shocking the world because it has infected thousands of millions of global people in a short time. Anticipating the spread and increase in the number of patients, the application of health protocols needs to be done by the community. Some health protocols during the Corona pandemic period are wearing masks, applying social distancing or physical distancing, maintaining hand hygiene and applying the ethics of coughing and sneezing. So this study aims to determine the level of public awareness in the application of health protocols during the Corona virus pandemic. This study uses a cross-sectional method and an observational study. While the data collection process was carried out through google survey and whatsapp with a total sample of 130 participants. Based on the data obtained, most people have implemented several health protocols such as wearing masks, applying social distancing or physical distancing and applying the ethics of coughing and sneezing well. But the implementation of health protocols such as maintaining hand hygiene has not been done well. 52.3 percent and 56.9 percent of participants did not wash their hands before eating and did not bring hand sanitizers when traveling as a form of self protection.
\end{abstract}

\section{PENDAHULUAN}

Corona virus merupakan virus jenis baru yang kini telah menggemparkan masyarakat dunia (Mona, 2020). Masalahnya virus ini telah berhasil menginfeksi ribuan juta masyarakat global dalam waktu yang sangat singkat ( $\mathrm{Li}$ et al., 2020). Bahkan manusia tanpa menunjukkan gejala terinfeksi Corona virus dapat pula menyebarkan kepada manusia lainnya (Kumar \& Dwivedi, 2020).

Mengantisipasi peningkatan penyebaran dan jumlah infeksi, masyarakat dihimbau untuk melakukan pola hidup sehat baru sesuai protokol kesehatan semasa pandemi Corona virus. Salah 
satu bentuk protokol tersebut adalah menjaga kebersihan dan tidak melakukan kontak langsung dengan pasien positif Corona virus (Izzaty, 2020). Kemudian, menggunakan masker pelindung wajah saat bepergian atau diluar rumah (Howard et al., 2020). Selanjutnya, menjaga kebersihan dengan mencuci tangan atau menggunakan handsanitizer (Lee et al., 2020). Terakhir adalah penerapan social distancing dengan menjaga jarak sejauh 1 meter dan menutup mulut saat batuk atau bersin menggunakan lengan(Hafeez et al., 2020).

Beberapa contoh protokol kesehatan tersebut tentu sangat perlu untuk diterapkan masyarakat selama masa pandemi Corona virus. Bahkan protokol social distancing seperti isolasi diri telah diumumkan pemerintah melalui surat edaran Nomor H.K.02.01/MENKES/202/2020. Selain agar terhindar dari infeksi Corona virus, proses penekanan penyebaran dan infeksi Corona virus dapat dilakukan. Berdasarkan hal tersebut, maka penelitian ini ditulis dengan maksud untuk menganalisis tingkat kesadaran masyarakat dalam penerapan protokol kesehatan selama masa pandemi Corona virus.

\section{Penerapan Protokol Kesehatan}

Belum ditemukannya antiviral spesifik sebagai vaksin merupakan alasan terbesar penerapan protokol kesehatan semasa pandemik (Gennaro et al., 2020). Protokol kesehatan tersebut berfungsi sebagai pencegah penyebaran infeksi Corona virus kepada masyarakat luas. Beberapa contoh protokol kesehatan yang telah diterbitkan pemerintah Indonesia selama masa pandemi Corona virus yaitu: a) Menggunakan masker; b) Menutup mulut ketika batuk dan bersin dikeramaian; c) Istirahat dengan cukup apabila suhu badan $38^{\circ} \mathrm{C}$ atau lebih serta batuk dan pilek; d) Larangan menggunakan transportasi umum bagi masyarakat yang sedang sakit; e) Jika terdapat masyarakat yang memenuhi keriteria suspek maka akan dirujuk ke rumah sakit Covid atau melakukan isolasi (Kantor Staf Presiden, 2020).

\section{Fungsi Masker Pelindung Wajah}

Masker pelindung wajah merupakan salah satu bentuk self protection selama masa pandemi Corona virus. Pernyataan tersebut juga telah diperkuat oleh World Health Organization (WHO) melalui panduan sementara yang diumumkan pada tanggal 06 April 2020 mengenai anjuran mengenaikan masker (World Health Organization, 2020b). Masker pelindung wajah sangat penting digunakan karena tidak hanya berfungsi sebagai pelindung, tapi juga sebagai pencegah penyebaran infeksi Corona virus (Shen et al., 2020). Melalui penggunaan masker pelindung wajah, proses penyebaran Corona virus juga dapat dikendalikan (Cheng et al., 2020).

Masker pelindung wajah terdiri atas beberapa jenis yaitu; masker medis dan masker respirator. Masker medis merupakan masker sekali pakai yang waktu pakainya maksimal \pm 4 jam dan tidak dapat digunakan kembali ketika basah (Lepelletier et al., 2020). Masker medis memiliki tingkat penetrasi partikel 44\%, sehingga mampu melindungi diri dari virus dan tidak beresiko memunculkan penyakit lain (Szarpak et al., 2020). Masker respiratori merupakan salah satu media penyaring dalam bentuk topeng. Masker respiratori berfungsi sebagai salah satu alat pelindung petugas kesehatan yang terpapar virus (Ippolito et al., 2020).

Pada masa pandemi ini jumah masker medis maupun masker respirator sangatlah terbatas. Menanggapi hal tersebut, masyarakat mulai menggunakan masker kain sebagai bentuk self protection. Melalui panduan interm 05 Juni 2020, World Health Organization (WHO) juga telah menghimbau penggunaan masker medis maupun non-medis bagi masyarakat umum (World Health Organization, 2020a). Keriteria masker kain sendiri menurut dr. Reisa Broto agar dapat mencegah penyebaran infeksi Corona virus adalah sebagai berikut; a) Masker terdiri atas 3 lapis; b) Kain pertama adalah kain katun, kain ke-dua adalah kain yang bisa mendukung viltrasi optimal (katun atau polyester) dan kain ke-tiga adalah lapisan hidrofobik atau anti air (polypropylene) (Kementerian Kesehatan Republik Indonesia, 2020). 


\section{Mencuci Tangan}

Menjaga kebersihan diri selama masa pandemi Corona virus seperti mencuci tangan merupkan salah satu langkah yang perlu dilakukan masyarakat. World Health Organization (WHO) juga telah menjelaskan bahwa menjaga kebersihan tangan telah mampu menyelamatkan nyawa manusia dari infeksi Corona virus (World Health Organization, 2020d). Meski demikian, mencuci tangan tidak bisa dilakukan dengan sembarangan oleh masyarakat. Mencuci tangan dengan benar dalam waktu 20 detik atau lebih menggunakan air mengalir dan sabun cair merupakan cara efektif yang dianjurkan dan sangat perlu masyarakat terapkan (Khedmat, 2020). Melalui tindakan mencuci tangan siklus transmisi dan resiko penyebaran Corona virus antara $6 \%$ dan $44 \%$ dapat dikurangi (Chen et al., 2020).

\section{Menggunakan Handsanitizer}

Menggunakan hand sanitizer merupakan cara lain untuk menjaga kebersihan tangan selain mencuci tangan menggunakan sabun dan air mengalir. Hal tersebut dikarenakan Hand sanitizer mampu mencegah terjadinya infeksi mikroba pada manusia (Dewi et al., 2016). Pada hand sanitizer atau antiseptic yang mengandung sebanyak 62\%-95\% alkohol mampu melakukan denaturasi protein mikroba dan mampu menonaktifkan virus (Lee et al., 2020). Melihat hal tersebut, maka proses penyebaran dan infeksi Corona virus pada masyarakat tentu dapat diminimalisir.

Meski penggunaan hand sanitizer atau antiseptic dianjurkan selama masa pandemi Corona virus, namun pemakaian hand sanitizer secara terus-menerus sangat tidak dianjurkan karena dapat menyebabkan iritasi dan luka bakar pada kulit(Asngad, A., Bagas, A.R., 2018). Sehingga penggunaan hand sanitizer lebih baik dilakukan saat berada di luar rumh atau saat tidak ada fasilitas mencuci tangan dengan sabun dan air mengalir.

\section{Social Distancing}

Social distancing merupakan salah satu kebijakan yang kini diterapkan masyarakat dunia selama masa pandemi Corona virus. Selama menjalankan kebijakan Social distancing pemerintah Indonesia telah menerapkan beberapa kegiatan seperti: a) Belajar dan bekerja dari rumah; b) Tinggal di rumah; c) Melarang kegiatan dikermaian dan; d) Membatasi jam operasional di tempat umum(Yanti et al., 2020).

Tujuan dari kegiatan Social distancing atau physical distancing adalah meminimalisir interaksi antar masyarakat yang kemungkinan terdapat beberapa warga terinfeksi namun tidak melakukan self isolation (Suppawittaya et al., 2020). Selain itu kegiatan social distancing juga memiliki dampak signifikan dalam meminimalisir tingkat kejahatan akibat adanya krisis ekonomi selama masa pandemi Corona virus (Ippolito et al., 2020). Menurut Wold Health Organization (WHO) proses social distancing dapat dilakuan dengan menjaga jarak sejauh 1 meter atau 3 kaki dengan orang lain (World Health Organization, 2020c).

\section{Menutup Mulut Saat Batuk dan Bersin}

Penyebaran Corona virus di dunia ini telah berlangsung dengan cepat dengan jutaan jumlah pasien terinfeksi. Salah satu proses penyebarannya dapat melalui inhasi kontak secara langsung dengan tetesan droplet pasien terinfeksi (Singhal, 2020). Masalah yang kini muncul adalah adanya pasien terinfeksi yang tidak menunjukkan gejala sehingga proses penyebaran Corona virus sulit diidentifikasi (Nishiura et al., 2020).

Menindaklanjuti hal tersebut maka World Health Organization (WHO) menerapkan etika batuk dan bersin sebagai berikut: a) Menutup hidung dan mulut; b) Segera membuang tissue yang telah dipakai untuk menutup mulut ketika batuk atau bersin; c) Membersihkan tangan (World Health Organization, 2008). 
Etika tersebut perlu diterapkan oleh masyarakat sebagai bentuk self protection agar terhindar dari infeksi Corona virus.

\section{METODE}

Penelitian ini menggunakan metode cross-sectional dan studi observasional. Kemudian tujuan observasi dalam penelitian ini adalah untuk menganalisis perubahan kebiasaan pola hidup sehat apa saja yang telah masyarakat lakukan selama masa pandemi corona virus. Mengingat kebiasaan pola hidup sehat baru seperti; menggunakan masker, mencuci tangan dengan air mengalir dan sabun cair, menggunkaan hand sanitizer, social distancing serta menutup mulut saat batuk dan bersin sangat perlu dilakukan masyarakat dalam menangani wabah pandemi Corona virus. Teknik sampling dalam penelitian ini adalah Teknik probabilitas. Sedangkan jumlah sampel dalam penelitian ini sebanyak 130 sampel. studi populasi penelitian ini adalah masyarakat dengan usia 18-50 tahun. kriteria sampel dalam penelitian ini adalah: a) Masyarakat berusia 18-50 tahun; b) Memiliki smartphone dan akses internet untuk mengisi kuisioner secara online atau tidak langsung;

Pengecualian kriteria sampel penelitian ini adalah apabila: a) Masyarakat tidak ingin berpartisipasi; b) Sampel berusia dibawah 18 tahun dan diatas 50 tahun. Proses ethnical permission dalam penelitian ini telah dilakukan dengan pengiriman file dengan respon setuju maupun tidak setuju untuk selanjutnya mengisi kuisioner.

Alat studi: Penelitian ini menggunakan kuisioner baik secara online maupun langsung untuk mendapatkan data sampel. Bentuk dan struktur kuisioner penelitian ini disesuaikan dengan sumber literature penelitian sebelumnya serta konsultasi dengan para ahli.

Uji Coba Instrumen: Uji coba instrument sangat penting dilakukan untuk mengetahui kelayakan instrument serta tanggapan peserta sampel dalam penelitian. Pemrosesan Data: Peneitian ini menggunakan studi cross-sectional dan observasi yang dilakuan pada masyarakat Indonesia. Proses pengambilan data dalam penelitian ini dilakukan melalui tautan berbasis web melalui google survey dan melalui whatsapp yang merupakan platform populer untuk berbagi dan berdiskusi. Privasi peserta dalam penelitian ini dilindungi secara ketat sesuai dengan etika. Proses pengambilan data pada penelitian ini dimulai sore hari pukul 15.30 tanggal 03 Juli 2020 dan ditutup sore hari pada tanggal 06 Juli 2020 pukul 15.30.

\section{HASIL DAN PEMBAHASAN}

Tabel 1

Profil responden pengisi kuesioner

\begin{tabular}{|c|c|}
\hline Tabel profil responden & Jumlah (\%) \\
\hline \multicolumn{2}{|l|}{ Usia (tahun) } \\
\hline $18-25$ tahun & 90 \\
\hline 26-35 tahun & 5.4 \\
\hline 36-50 tahun & 4.6 \\
\hline \multicolumn{2}{|l|}{ Gender } \\
\hline Perempuan & 69.2 \\
\hline Laki-laki & 30.8 \\
\hline \multicolumn{2}{|l|}{ Profesi } \\
\hline Pelajar & 70 \\
\hline Pekerja & 25.3 \\
\hline Belum bekerja atau tidak bekerja & 12.3 \\
\hline
\end{tabular}

Tabel 1 menampilkan profil peserta pengisi kuesioner dalam penelitian. Peserta pengisi kuesioner pada penelitian ini memiliki umur antara 18-50 tahun yang terbagi atas usia 18-25 tahun (90\%), 26-35 tahun (5.4\%) dan 36-50 tahun (4.6\%). Kemudian lebih dari setengah yaitu 69.2\% 
peserta adalah perempun, sedangkan sebanyak $30.8 \%$ adalah peserta laki-laki. Seluruh peserta pengisi kuesioner penelitian ini memiliki profesi yang beragam seperti; pelajar (70\%), pekerja $(25.3 \%)$ dan tidak bekerja atau belum bekerja (12.3\%).

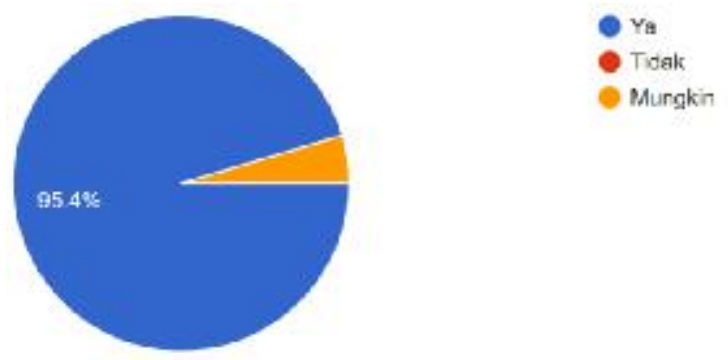

Diagram 1. Pentingnya penerapan Protokol Kesehatan

Diagram 1- merupakan hasil kuesioner yang menunjukkan tentang tanggapan masyarakat terhadap pentingnya penerapan protokol kesehatan selama masa pandemi Corona virus. Diagram tersebut menunjukkan bahwa sebagian besar masyarakat (95.4\%) menganggap bahwa penerapan protokol kesehatan selama masa pandemi Corona virus penting untuk dilakukan. Meski demikian masih terdapat sebagian kecil masyakat $(4.6 \%)$ yang belum sepenuhnya menganggap bahwa penerapan protokol kesehatan penting untuk dilakukan selama masa pandemi Corona virus.

Tabel 2. Pengetahuan masyarakat mengenai protokol kesehatan

\begin{tabular}{|c|c|c|}
\hline No. & Jenis Protokol & $\mathbf{N}(\%)$ \\
\hline 1. & Penggunaan masker & 23.1 \\
\hline 2. & Menjaga kebersihan tangan menggunakan air mengalir dan sabun & 21.5 \\
\hline 3. & Menjaga kebersihan tangan menggunakan hand sanitizer & 14.5 \\
\hline 4. & Melakukan social distancing atau physical distancing & 20 \\
\hline 5. & Menutup mulut saat batuk atau bersin & 16.9 \\
\hline 6. & Menganggap kegiatan 1-5 adalah protokol kesehatan & 87.7 \\
\hline
\end{tabular}

Sebagian besar masyarakat $(87.7 \%)$ telah mengetahui protokol kesehatan apa saja yang telah diterapkan oleh pemerintah selama masa pandemi Corona virus. Namun tidak sedikit warga yang hanya mengetahui sebagian dari protokol kesehatan. Bahkan protokol kesehatan seperti menjaga kebersihan tangan menggunakan hand sanitizer hanya diketahui sebanyak $14.5 \%$ masyarakat.

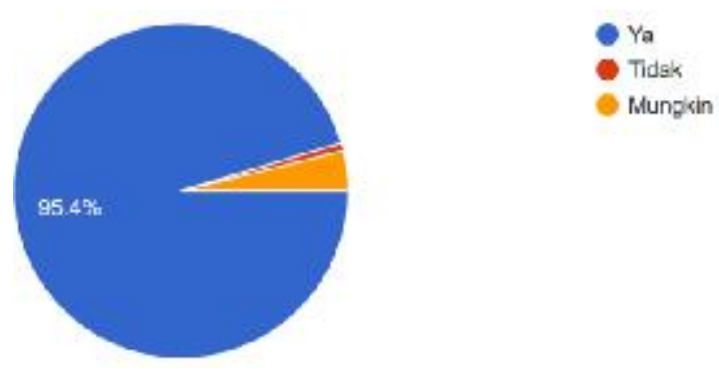

Diagram 2. pentingnya penggunaan masker

Diagram 2- merupakan hasil kuesioner mengenai pentingnya penggunaan masker saat bepergian atau berada di luar rumah. Diagram tersebut menunjukkan bahwa sebagian besar masyarakat (95.4\%) menganggap penggunaan masker saat berpergian penting untuk dilakukan. Namun sebanyak (3.8\%) masyarakat masih belum yakin dengan penggunaan masker saat bepergian 
atau diluar rumah selama masa pandemi, bahkan terdapat pula (0.8\%) masyarakat yang menganggap hal tersebut tidak penting untuk dilakukan.

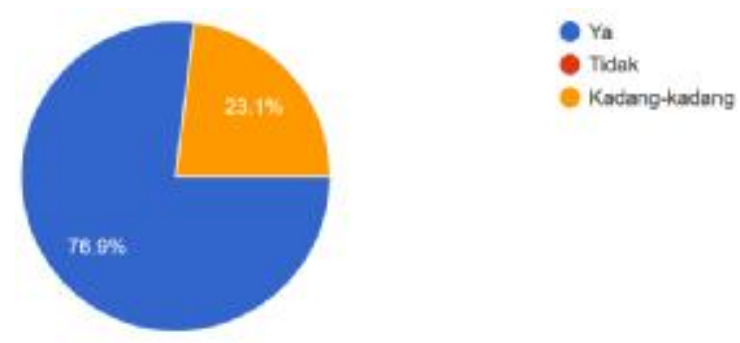

Diagram 3. kebiasaan masyarakat dalam mencuci atau mengganti masker

Diagram 3- merupakan hasil kuesioner yang menunjukkan tentang kebiasaan masyarakat dalam mencuci atau mengganti masker setelah menggunakannya untuk bepergian selama masa pandemi Corona virus. Berdasarkan hasil kuesioner diketahui sebanyak $23.1 \%$ masyarakat belum melakukan kebiasaan tersebut secara teratur. Namun tidak sedikit masyarakat yaitu sebanyak $76.9 \%$ yang mencuci dan mengganti masker mereka secara teratur setelah digunakan untuk bepergian selama masa pandemi Corona virus.

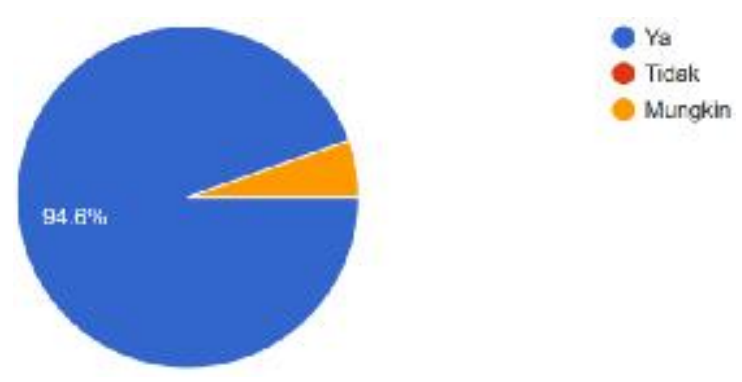

Diagram 4. perlunya menjaga kebersihan tangan

Diagram 4- menunjukkan tanggapan masyarakat mengenai perlunya menjaga kebersihan tangan selama masa pandemi Corona virus. Sebanyak 94.6\% masyarakat telah menganggap bahwa menjaga kebersihan tangan selama masa pandemi Corona virus perlu untuk dilakukan. Meski demikian masih terdapat $5.4 \%$ masyarakat yang mengganggap hal tersebut tidak perlu untuk dilakukan.

Tabel 3. Cara masyarakat menjaga kebersihan tangan

\begin{tabular}{clr}
\hline No. & \multicolumn{1}{c}{ Tindakan } & $\mathbf{N}(\boldsymbol{\%})$ \\
\hline 1. & Mencuci tangan sebelum makan & 47.7 \\
\hline 2. & Menggunakan hand sanitizer ketika berada di rumah & 13.8 \\
\hline 3. & Membawa hand sanitizer ketika bepergian & 43.1 \\
\hline 4. & Menggunakan hand sanitizer setiap menit & 10.8 \\
\hline 4. & Mencuci menggunakan air mengalir dan suban & 56.9 \\
\hline 5. & Mengusap tangan dengan kain basah & 2.3 \\
\hline 6. & Mengusap tangan dengan kain kering & 13.8 \\
\hline 7. & Melakukan tindakan 1-6 & 37.7 \\
\hline
\end{tabular}

Berdasarkan hasil kuesioner, diketahui bahwa terdapat beberapa masyarakat yang belum sepenuhnya faham mengenai cara menjaga kebersihan tangan. Hal tersebut ditunjukkan dengan adanya 10\% masyarakat yang meganggap bahwa menggunakan hand sanitizer setiap menit merupakan langkah benar untuk menjaga kebersihan tangan. Kemudian sebanyak $2.3 \%$ masyarakat 
juga menganggap bahwa mengusap tangan menggunakan kain basah adalah hal benar untuk menjaga kebersihan tangan. Meski demikian sebagian besar masyarakat telah faham mengenai cara menjaga kebersihan tangan dengan benar. Sebanyak $47.7 \%$ masyarakat telah mencuci tangan sebelum makan. Kemudian, sebanyak 56.9\% masyarakat telah menjaga kebersihan tangan dengan mencuci tangan menggunakan sabun dan air mengalir. Serta sebanyak 14.2\% masyarakat juga selalu membawa hand sanitizer saat bepergian.

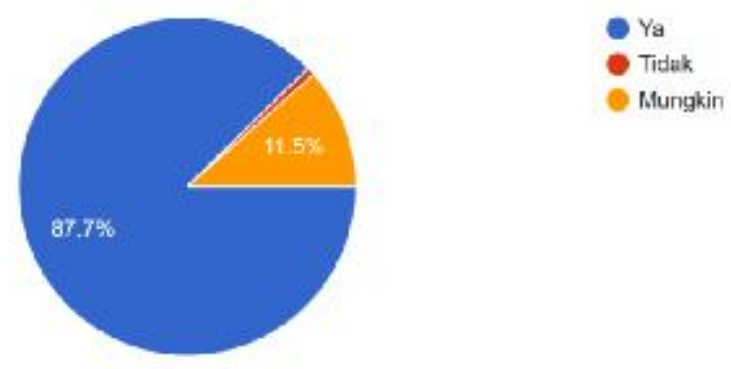

Diagram 5 perlunya penerapan social distancing

Diagram 5- menunjukkan tanggapan masyarakat mengenai perlunya penerapan social distancing atau physical distancing selama masa pandemi Corona virus. Sebagian besar masyarakat $87.7 \%$ menganggap bahwa social distancing atau physical distancing selama masa pandemi Corona virus perlu untuk dilakukan. Sebanyak $11.5 \%$ masyarakat belum yakin terhadap penerapan social distancing atau physical distancing, sedangkan sebanyak $0.8 \%$ masyarakat menganggap tidak perlu untuk melakukan social distancing atau physical distancing selama masa pandemi Corona virus.

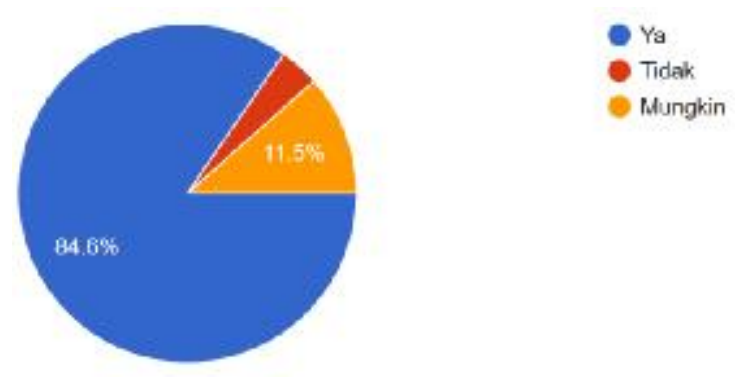

Diagram 6. perlunya menjaga jarak minimal 1 meter

Diagram 6- merupakan tanggapan masyarakat mengenai perlunya menjaga jarak minimal 1 meter saat berada di tempat umum selama masa pandemi Corona virus. Sebanyak $84.6 \%$ masyarakat menganggap hal tersebut perlu untuk dilakuan. Sebanyak $11.5 \%$ masyarakat menganggap bahwa menjaga jarak minimal 1 meter tidak begitu perlu dilakuan, bahkan sebanyak $3.8 \%$ masyarakat menganggap hal tersebut tidak perlu dilakukan.

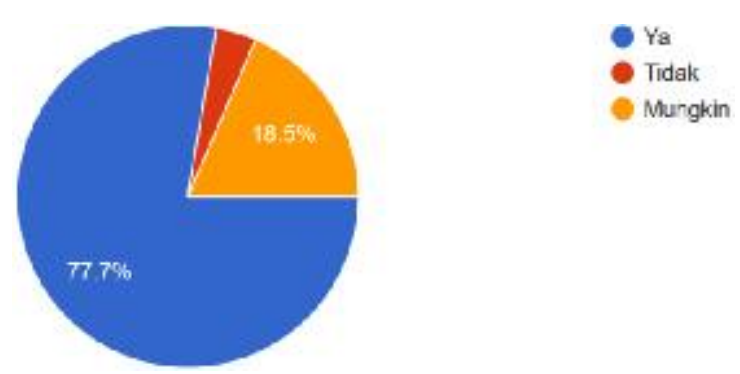

Diagram 7. Kebijakan berkumpul dan bepergian selama pandemi 
Diagram 7- menunjukkan tanggapan masyarakat mengenai aktivitas berkumpul dan bepergian selama masa pandemi Corona virus. Berdasarkan diagram diketahui sebanyak $18.5 \%$ masyarakat belum sepenuhnya yakin dengan kebijakan tersebut, bahkan sebanyak 3.8\% masyarakat menganggap bahwa bepergian dan berkumpul perlu untuk dilakukan. Meski demikian sebanyak $77.7 \%$ masyarakat berpendapat bahwa kegiatan tersebut tidak perlu untuk dilakukan selama masa pandemi Corona virus.
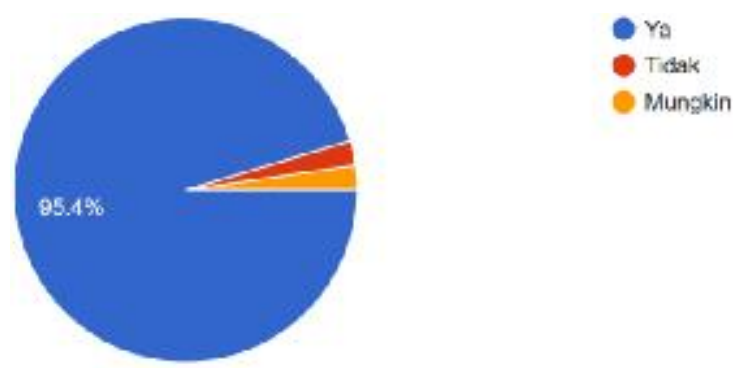

Diagram 8. tanggapan mengenai etika batuk dan bersin

Diagram 8- merupakan hasil tanggapan masyarakat mengenai etika batuk dan bersin selama masa pandemi Corona virus. Menurut diagram sebanyak 95.4\% masyarakat beranggapan bahwa menutup mulut dn hidung saat batuk maupun bersin perlu untuk dilakukan. Sedangkan $2.3 \%$ masyarakat tidak begitu mempermasalahkan etika batuk dan bersin selama masa pandemi Corona virus dan 2.3\% masyarakat lainnya mengangap bahwa hal tersebut tidak perlu untuk dilakukan.

\section{PEMBAHASAN}

Protokol kesehatan merupakan cara yang perlu diterapkan untuk mencegah penyebaran kasus infeksi Corona virus. Hal tersebut perlu dilakukan karena belum ditemukannya antiviral spesifik yang dapat digunakan sebagai vaksin (Gennaro et al., 2020., Yuliana, Y. 2020). Melihat hal itu, tentu masyarakat perlu untuk tahu dan menerapkan beberapa protokol kesehatan selama masa pandemi Corona virus.

Berdasarkan hasil kuesioner dengan jumlah 130 peserta, sebanyak 95,4\% peserta beranggapan bahwa protokol kesehatan perlu diterapkan selama masa pandemi Corona virus. Selain itu, sebanyak $87.7 \%$ peserta telah mengetahui beberapa jenis protokol kesehatan yang perlu dilakukan dan telah diterapkan oleh pemerintah.

Salah satu dari beberapa protokol kesehatan selama masa pandemi Corona virus adalah penggunaan masker saat bepergian. Berdasarkan hasil kuesioner sebanyak 95,4\% peserta telah menerapkan protokol penggunaan masker dengan baik dan benar. Hal tersebut sangat perlu dilakukan karena dengan menggunakan masker penyebaran kasus infeksi Corona virus dapat dikendalikan (Cheng et al., 2020).

Selain itu sebagian besar peserta $(76,9 \%)$ juga telah faham mengenai kegiatan mencuci atau mengganti masker setelah digunakan untuk bepergian. Kegiatan tersebut penting dilakukan karena penggunaan masker dalam waktu lama tidak dianjurkan dan dapat mengakibatkan munculnya penyakit lain (Szarpak et al., 2020). Meski demikian sebanyak $23.1 \%$ peserta masih jarang mengganti atau mencuci masker mereka setelah digunakan untuk bepergian.

Bentuk lain dari protokol kesehatan adalah menjaga kebersihan tangan dengan benar dan baik. Berdasarkan hasil kuesioner sebanyak 94,6\% peserta menganggap bahwa menjaga kebersihan tangan selama masa pandemi Corona virus perlu dilakukan. Sebagian besar peserta $(56,9 \%)$ telah menjaga kebersihan tangan mereka dengan mencuci menggunakan sabun dan air mengalir. Namun tidak sedikit peserta yang belum menjaga kebersihan tangan mereka dengan baik dan benar. 
Padahal menjaga kebersihan tangan selama masa pandemi Corona virus dapat mengurangi proses penyebaran (Chen et al., 2020).

Kurangnya kesadaran dalam menjaga kebersihan tangan ditunjukkan dengan sebanyak 52,3\% peserta tidak mencuci tangan sebelum makan. Padahal mencuci tangan dapat mengurangi resiko penyebaran virus sebanyak 55\% (Chen et al., 2020). Selain itu, mencuci tangan adalah kegiatan yang mudah dilakukan dan efektif dalam mengurangi resiko infeksi (Jamie, 2020). Kemudian sebanyak 56,9\% peserta tidak membawa hand sanitizer sebagai bentuk self protection ketika berada di luar rumah. Padahal hand sanitizer yang mengandung etanol memiliki aktivitas virucidal (Kampf, 2018). Sehingga dengan menggunakan hand sanitizer, proses infeksi mikroba (virus) pada manusia dapat dicegah (Dewi et al., 2016).

Selanjutnya adalah penerapan protokol kesehatan untuk social distancing atau physical distancing. Pada protokol kesehatan tersebut, sebagian besar peserta $(87.7 \%)$ menganggap hal itu perlu untuk dilakukan. Sebanyak $84,6 \%$ peserta telah membuktikan perlunya social distancing atau physical distancing dengan menjaga jarak minimal sejauh 1 meter. Selain itu, sebanyak 77,7\% peserta juga tidak bepergian dan berkumpul dengan orang lain selama masa pendemi Corona virus. Kegiatan tersebut tentu sangat perlu dilakukan karena melalui social distancing proses interaksi antar masyarkat dapat di minialisir, sehingga penyebaran virus Corona dari orang satu ke orang yang lain dapat dihindari (Suppawittaya et al., 2020).

Protokol kesehatan lain yang perlu diterapkan adalah menjaga etika saat batuk dan bersin. Berdasarkan hasil kuesioner, hampir seluruh peserta $(95,4 \%)$ beranggapan bahwa menutup mulut saat batuk dan besin penting untuk dilakukan. Hal tersebut dikarenakan penyebaran Corona virus dapat melalui inhasi kontak langsung dan melalui tetesan droplet (Singhal, 2020). Selain itu, saat ini telah muncul beberapa kasus pasien terinfeksi Corona virus tanpa menunjukkan gejala (Gao et al., 2020). Sehingga penerapan etika batuk dan bersin dapat melindungi masyarakat dari pasien terinfeksi tanpa gejala yang mungkin tidak melakuan isolasi (Nishiura et al., 2020).

\section{SIMPULAN DAN SARAN}

Berdasarkan data yang didapatkan, sebagian besar masyarakat telah menerapkan beberapa protokol kesehatan seperti; menggunakan masker, penerapan social distancing atau physical distancing dan penerapan etika batuk dan bersin dengan baik. Namun penerpan protokol kesehatan seperti menjaga kebersihan tangan belum dilakukan dengan benar. Sebanyak 52,3\% dan 56,9\% peserta tidak mencuci tangan sebelum makan dan tidak membawa hand sanitizer saat bepergian sebagai bentuk self protection.

Berdasarkan hasil kuesioner, menunjukkan bahwa masyarakat belum menerapkan protokol kesehatan dengan baik. Bahkan sebagian besar masyarakat tidak melakukan protokol untuk menjaga kebersihan tangan. Meski demikan perlu diketahui faktor penyebab tidak diterapkannya protokol kesehatan dengan baik oleh masyarakat. Sehingga penelitian selanjutnyas angat perlu untuk mengetahui faktor-faktor tersebut. 


\section{DAFTAR PUSTAKA}

Asngad, A., Bagas, A.R., dan N. (2018). Kualitas pembersih Tangan Hand Sanitizer. Bioeksperimen, 4(2), 61-70. https://doi.org/10.23917/bioeksperimen.v4i1.2795

Chen, X., Ran, L., Liu, Q., Hu, Q., Du, X., \& Tan, X. (2020). Hand Hygiene, Mask-Wearing Behaviors and Its Associated Factors during the COVID-19 Epidemic: A Cross-Sectional Study among Primary School Students among Primary School Students in Wuhan, China. International Journal of Environmental Research and Public Health, 17(8), 2-11. https://doi.org/10.3390/ijerph17082893

Cheng, V. C., Wong, S., Chuang, V. W., So, S. Y., Chen, J. H., Sridhar, S., To, K. K., Chan, J. F., Hung, I. F., Ho, P., \& Yuen, K. (2020). The Role of Community-Wide Wearing of Face Mask For Control of Coronavirus Disease 2019 ( COVID-19 ) Epidemic Due to SARS-CoV2. Journal of Infection, 81, 107-114. https://doi.org/10.1016/j.jinf.2020.04.024

Dewi, D. W., Khotimah, S., \& Liana, D. F. (2016). Pemanfaatan Infusa Lidah Buaya (Aloe vera L ) Sebagai Antiseptik Pembersih Tangan Terhadap Jumlah Koloni Kuman. Jurnal Cerebellum, 2, 577-589.

Gao, Z., Xu, Y., Sun, C., Wang, X., Guo, Y., Qiu, S., \& Ma, K. (2020). A systematic Review of Asymptomatic Infections with COVID-19. Journal of Microbiology, Immunology and Infection, $x x x x, 1-5$. https://doi.org/10.1016/j.jmii.2020.05.001

Gennaro, F. Di, Pizzol, D., Marotta, C., Antunes, M., Racalbuto, V., Veronese, N., \& Smith, L. (2020). Coronavirus Diseases ( COVID-19) Current Status and Future Perspectives: A Narrative Review. International Journal of Environmental Research and Public Health, 17, $2-11$.

Hafeez, A., Ahmad, S., Siddqui, S. A., Ahmad, M., \& Mishra, S. (2020). A Review of COVID-19 (Coronavirus Disease-2019) Diagnosis Trearments and Prevention. Eurasian Journal of Medicine and Oncologi, 4(2), 116-125. https://doi.org/10.14744/ejmo.2020.90853

Howard, J., Howard, J., Huang, A., Li, Z., Tufekci, Z., Zdimal, V., \& Westhuizen, H. Van Der. (2020). Face Masks Against COVID-19: An Evidence Review Face Masks Against COVID19: An Evidence Review. Preprints, 30(20), 1-9. https://doi.org/10.1073/pnas.XXXXXXXXXX

Ippolito, M., Vitale, F., Accurso, G., Iozzo, P., Gregoretti, C., Giarratano, A., \& Cortegiani, A. (2020). Medical masks and Respirators for the Protection of Healthcare Workers From SARS-CoV-2 and Other Pulmonology. https://doi.org/10.1016/j.pulmoe.2020.04.009

Izzaty. (2020). Kebijakan Pemerintah dalam Mengatasi Panic Buying Akibat COVID-19. Info Singkat, 12(1), 20-30.

Jamie, A. H. (2020). Hand Washing Practices among Health Care Workers in Jugal Hospital, Harar, Ethiopia, 2020: In the Era of Corona Virus: Observational Study. Journal of Antivirals \& Antiretrovirals Research, 12, 5-9. https://doi.org/10.35248/1948-5964.20.12.197

Kampf, G. (2018). Efficacy of Ethanol Against Viruses in Hand Disinfection. Journal of Hospital Infection, 98(4), 331-338. https://doi.org/10.1016/j.jhin.2017.08.025

Kantor Staf Presiden. (2020). Pemerintah Terbitkan Protokol Kesehatan Penanganan COVID-19. Berita KSP. http://ksp.go.id/index.html

Kementerian Kesehatan Republik Indonesia. (2020). Begini Aturan Pemakaian Masker Kain yang Benar (pp. 1-2). https://www.kemkes.go.id/article/view/20060900002/begini-aturanpemakaian-masker-kain-yang-benar.html 
Khedmat, L. (2020). New Coronavirus (2019-nCoV): An Insight Toward Preventive Actions and Natural Medicine. International Travel Medicine Center of Iran, 8(1), 44-45. https://doi.org/10.34172/ijtmgh.2020.07

Kumar, M., \& Dwivedi, S. (2020). Impact of Coronavirus Imposed Lockdown on Indian Population and their Habits. 5(June), 88-97.

Lee, J., Jing, J., Yi, T. P., Bose, R. J. C., Mccarthy, J. R., Tharmalingam, N., \& Madheswaran, T. (2020). Hand Sanitizers: A Review on Formulation Aspects , Adverse E ff ects , and Regulations. International Journal of Environmental Research and Public Health, 17, 2-17.

Lepelletier, D., Grandbastien, B., Romano-bertrand, S., \& Aho, S. (2020). What Face Mask For What Use in the Context of the COVID-19 Pandemic? The French Guidelines. Journal of Hospital Infection, 105, 414-418. https://doi.org/10.1016/j.jhin.2020.04.036

Li, S., Wang, Y., Xue, J., Zhao, N., \& Zhu, T. (2020). The impact of covid-19 epidemic declaration on psychological consequences: A study on active weibo users. International Journal of Environmental Research and Public Health, 17(6), 1-9. https://doi.org/10.3390/ijerph17062032

Mona, N. (2020). Konsep Isolasi Dalam Jaringan Sosial Untuk Meminimalisasi Efek Contagious ( Kasus Penyebaran Virus Corona Di Indonesia). Jurnal Sosial Humaniora Terapan, 2(2), $117-125$.

Nishiura, H., Jung, S., Kinoshita, R., \& Yuan, B. (2020). Estimation of the asymptomatic ratio of novel coronavirus infections ( COVID- International Journal of Infectious Diseases. International Journal of Infectious Diseases, May, 19-21. https://doi.org/10.1016/j.ijid.2020.03.020

Shen, K., Yang, Y., Wang, T., Zhao, D., Jiang, Y., Jin, R., Zheng, Y., Xu, B., Xie, Z., Lin, L., Shang, Y., Lu, X., Shu, S., Bai, Y., Deng, J., Lu, M., Ye, L., Wang, X., Wang, Y., \& Gao, L. (2020). Diagnosis , treatment, and prevention of 2019 novel coronavirus infection in children: experts ' consensus statement. World Journal of Pediatrics, February. https://doi.org/10.1007/s12519-020-00343-7

Singhal, T. (2020). A Review of Coronavirus Disease-2019 (COVID-19). The Indian Journal of Pediatrics, 87(April), 281-286.

Suppawittaya, P., Yiemphat, P., \& Yasri, P. (2020). Effects of Social Distancing, Self-Quarantine and Self-Isolation during the COVID-19 Pandemic on People's Well -Being, and How to Cope with It. International Journal of Science and Healthcare Research, 5(June), 12-20.

Szarpak, L., Smereka, J., \& Filipiak, K. J. (2020). Cloth Masks Versus Medical Masks for COVID19 Protection. Cardiology Journa, 27(April), 10-12. https://doi.org/10.5603/CJ.a2020.0054

World Health Organization. (2008). Epidemic-Prone and Pandemic-Prone Acute Respiratory Diseases: Infection Prevention and Control in Helath-Care Facilities. Who. Indonesia Partner in Development, 53(2), 8-25. https://doi.org/10.1017/CBO9781107415324.004

World Health Organization. (2020a). Anjuran Mengenai Penggunaan Masker dalam Konteks COVID-19. World Health Organization. https://www.who.int/infectionprevention/campaigns/clean-hands/en/

World Health Organization. (2020b). Anjuran Mengenai Penggunaan Masker dalam Konteks Covid. In World Health Organization (Issue April). https://www.who.int/docs/defaultsource/searo/indonesia/covid19/anjuran-mengenai-penggunaan-masker-dalam-kontekscovid-19.pdf?sfvrsn=8a209b04_2 
World Health Organization. (2020c). Coronavirus Disease (COVID-19) Situation Report. World Health Organization. https://www.who.int/emergencies/diseases/novel-coronavirus2019/situation-reports

World Health Organization. (2020d). Hand Hygiene in Health Care First Global Patient Safety Challenge Clean Care is Safer Care. In World Health Organization (Vol. 30, Issue 1). https://doi.org/10.1086/600379

Yanti, B., Mulyadi, E., Wahiduddun, Novika, R. G. H., Ariana, Y. M. D., Martani, N. S., \& Nawan. (2020). Community Knowledge, Attitudes, and Behavior Towards Social Distancing Policy As Prevention Transmission of Covid-19 in Indonesia. Jurnal Administrasi Kesehatan Indonesia, 8(1), 4-14. https://doi.org/10.20473/jaki.v8i2.2020.4-14

Yuliana, Y. (2020). Corona virus diseases (Covid-19): Sebuah tinjauan literatur. Wellness And $\begin{array}{llllll}\text { Healthy } & \text { Magazine, } & 2(1), & 187 & - & 192 .\end{array}$ from https://wellness.journalpress.id/wellness/article/view/21026 


\section{KETERANGAN DIAGRAM DAN GRAFIK PENELITIAN}

\section{Diagram 1.}

Menjelaskan hasil kuesioner tentang: Apakah menurut kalian penerapan protokol kesehatan selama masa pandemi Corona virus perlu untuk dipatuhi.

\section{Diagram 2.}

Menjelaskan hasil kuesioner tentang:: Apakah menggunakan masker saat berpergian atau diluar rumah selama masa pandemi Corona virus penting untuk dilakuan.

Diagram 3.

Menjelaskan hasil kuesioner tentang: Apakah kalian selalu mencuci atau mengganti masker setelah digunakan untuk berpergian.

Diagram 4.

Menjelaskan hasil kuesioner tentang: Apakah menjaga kebersihan tangan selama masa pandemi Corona virus perlu untuk dilakukan.

Diagram 5.

Menjelaskan hasil kuesioner tentang: Apakah penerapan social distancing atau physical distancing selama masa pandemi Corona virus perlu untuk dilakukan.

Diagram 6.

Menjelaskan hasil kuesioner tentang: Apakah menjaga jarak minimal 1 meter dengan orang lain ketika berada di tempat umum perlu untuk dilakukan

\section{Diagram 7.}

Menjelaskan hasil kuesioner tentang: Apakah tidak bepergian dan berkumpul dengan banyak orang selama masa pandemi Corona virus perlu untuk dilkukan.

\section{Diagram 8.}

Menjelaskan hasil kuesioner tentang: Apakah menutup mulut dan hidung saat bersin atau batuk penting untuk dilakukan selama masa pandemic Corona virus. 